\title{
Heavy Metals Assessment in an Urban Artificial Lake in Chennai, India
}

\author{
Daniel Rosado $^{1,2,3}$, Franco Castillo ${ }^{1}$, Indumathi Nambi ${ }^{2}$, Nicola Fohrer ${ }^{1}$ \\ ${ }^{1}$ Department of Hydrology and Water Resources Management, \\ Institute for Natural Resource Conservation, Kiel University \\ 24118 Kiel, Germany \\ drosado@hydrology.uni-kiel.de; nfohrer@hydrology.uni-kiel.de \\ ${ }^{2}$ Department of Civil Engineering, Indian Institute of Technology Madras \\ 600036 Chennai, India \\ indunambi@iitm.ac.in \\ ${ }^{3}$ Indo-German Centre for Sustainability, Indian Institute of Technology Madras, \\ 600036 Chennai, India \\ drosado@hydrology.uni-kiel.de
}

\section{Extended Abstract}

Chennai, the fourth-largest urban agglomeration in India, faces several water-related risks [1]. Water for human consumption is scarce out of the monsoon season. Wetlands and rivers are commonly polluted because of the frequent uncontrolled discharge of untreated sewage and industrial wastewater. Furthermore, garbage dumping adds another source of pollution to many urban lakes, threatening its biodiversity [2]. Many tanks (artificial lakes) were constructed in Chennai in former times to store rain water during the monsoon season that was used for irrigation during the dry season. The tanks were usually made by damming intermittent streams using crescent-shaped earthen bunds in a cascade down the axes of shallow inland valleys. However, tanks were abandoned and consequently degraded when they became exclusively ornamental due to the shift to groundwater as a source for water provision [3]. Little is known about pollution in the tanks of Chennai, particularly heavy metals. Thus, this study focuses on analysing heavy metal pollution in one of the urban tanks of the city, the Sembakkam Lake, and evaluate their potential effects on the ecosystem.

During four sampling campaigns in 2019, $\mathrm{pH}$, and conductivity were measured in situ in the water, and samples of water, and sediment were collected to measure $\mathrm{Al}, \mathrm{As}, \mathrm{Cr}, \mathrm{Cu}, \mathrm{Fe}, \mathrm{Mn}, \mathrm{Ni}, \mathrm{Pb}$, and $\mathrm{Zn}$ with an inductively coupled plasma optical emission spectrometer (ICP-OES). The results indicated that the average $\mathrm{pHs}$ in the four campaigns were in the range of neutral-alkaline (7.9-8.5) and conductivities were relatively high $(1560-2860 \mu \mathrm{S} / \mathrm{cm})$. Regarding heavy metals in water, there is a risk for aquatic life, since some $\mathrm{Pb}$ measurements are classified as class IV by the United Nations Economic Commission for Europe, i.e. above the midpoint between natural and chronically toxic levels and excursions beyond chronic criteria. As other elements, $\mathrm{Pb}$ is known to bioaccumulate in organisms and cause toxic effects. $\mathrm{Cu}$ and $\mathrm{Cr}$ were in the range of class II, indicating below the midpoint between natural and chronically toxic levels. In sediment, concentrations of $\mathrm{Ni}$ were above the effects range-median (ERM), a probable-effects range within which effects would frequently occur. $\mathrm{Cr}$ and $\mathrm{Cu}$ were between effects range-low (ERL) and ERM, a possible-effects range within which effects would occasionally occur. Untreated sewage and wastes in the lake could be attributed to these values. Therefore, proper management of sewage and waste is necessary to diminish the potentially deleterious effects of metals on aquatic life.

\section{References}

[1] U. Kelkar, P. Balachandra, and A. Gurtoo, "Assessing Indian Cities for Vulnerability to Climate Change," 2nd Int. Conf. Environ. Sci. Dev., vol. 4, pp. 246-250, 2011.

[2] T. Lan, E. Almered Olson, and S. Alpokay, Environmental Stresses and Resource Use in Coastal Urban and PeriUrban Regions DPSIR Approach to SECOA's 17 Case Studies. Rome: Sapienza Universitá Editrice, 2014.

[3] K. Palanisami, M. Jegadeesan, K. Fujita, and Y. Kono, "Impacts of the Tank Modernization Programme on Tank Performance in Tamil Nadu State, India,” Kyoto, 5, 2008. doi: 10.1017/CBO9781107415324.004. 